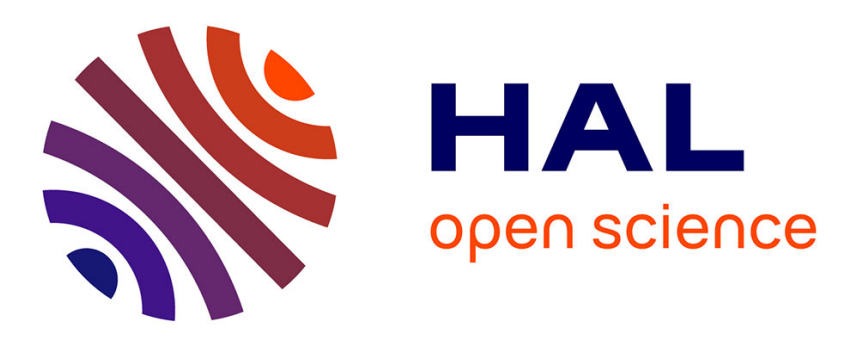

\title{
Influence of soil ageing on bioavailability and ecotoxicity of lead carried by process waste metallic ultrafine particles
}

Eva Schreck, Yann Foucault, Florence Geret, Philippe Pradère, Camille Dumat

\section{To cite this version:}

Eva Schreck, Yann Foucault, Florence Geret, Philippe Pradère, Camille Dumat. Influence of soil ageing on bioavailability and ecotoxicity of lead carried by process waste metallic ultrafine particles. Chemosphere, 2011, vol. 85, pp. 1555-1562. 10.1016/j.chemosphere.2011.07.059 . hal-00974830

\section{HAL Id: hal-00974830 \\ https://hal.science/hal-00974830}

Submitted on 7 Apr 2014

HAL is a multi-disciplinary open access archive for the deposit and dissemination of scientific research documents, whether they are published or not. The documents may come from teaching and research institutions in France or abroad, or from public or private research centers.
L'archive ouverte pluridisciplinaire HAL, est destinée au dépôt et à la diffusion de documents scientifiques de niveau recherche, publiés ou non, émanant des établissements d'enseignement et de recherche français ou étrangers, des laboratoires publics ou privés. 


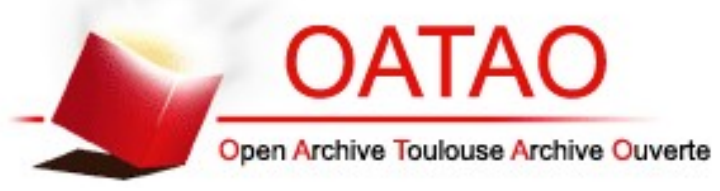

\section{Open Archive Toulouse Archive Ouverte (OATAO)}

OATAO is an open access repository that collects the work of Toulouse researchers and makes it freely available over the web where possible.

This is an author-deposited version published in: http://oatao.univ-toulouse.fr/ Eprints ID: 5514

To link to this article: DOI:10.1016/j.chemosphere.2011.07.059

http://dx.doi.org/10.1016/j.chemosphere.2011.07.059

To cite this version:

Schreck, Eva and Foucault, Yann and Geret, Florence and Pradère, Philippe and Dumat, Camille Influence of soil ageing on bioavailability and ecotoxicity of lead carried by process waste metallic ultrafine particles. (2011) Chemosphere, vol. 85 (n¹0). pp. 1555-1562. ISSN 0045-6535

Any correspondence concerning this service should be sent to the repository administrator: staff-oatao@inp-toulouse.fr 


\title{
Influence of soil ageing on bioavailability and ecotoxicity of lead carried by process waste metallic ultrafine particles
}

\author{
E. Schreck ${ }^{\mathrm{a}, \mathrm{b}}$, Y. Foucault ${ }^{\mathrm{a}, \mathrm{b}, \mathrm{c}}$, F. Geret $^{\mathrm{d}}$, P. Pradere ${ }^{\mathrm{c}}$, C. Dumat ${ }^{\mathrm{a}, \mathrm{b}, *}$ \\ a Université de Toulouse, INP, UPS, EcoLab (Laboratoire Ecologie Fonctionnelle et Environnement), ENSAT, Avenue de l'Agrobiopole, 31326 Castanet Tolosan, France \\ b CNRS, EcoLab, 31326 Castanet Tolosan, France \\ ' STCM, Société de Traitements Chimiques des Métaux, 30 Avenue de Fondeyre, 31200 Toulouse, France \\ ${ }^{\mathrm{d}}$ UMR CNRS 5602, Laboratoire GEODE, PRES Université de Toulouse, Centre Universitaire Jean-François Champollion, Place de Verdun, 81012 Albi Cedex 9 , France
}

\section{A R T I C L E I N F O}

\section{Keywords:}

Process metallic particles

Lead-recycling plant

Lettuce

Ageing

Root elongation

Microtox

\begin{abstract}
A B S T R A C T
Ultrafine particulate matters enriched with metals are emitted into the atmosphere by industrial activities and can impact terrestrial and aquatic ecosystems. Thus, this study investigated the environmental effects of process particles from a lead-recycling facility after atmospheric deposition on soils and potential run-off to surface waters. The toxicity of lead-enriched PM for ecosystems was investigated on lettuce and bacteria by (i) germination tests, growth assays, lead transfer to plant tissues determination and (ii) Microtox analysis.

The influence of ageing and soil properties on metal transfer and ecotoxicity was studied using three different soils and comparing various aged, spiked or historically long-term polluted soils. Finally, lead availability was assessed by $0.01 \mathrm{M} \mathrm{CaCl}_{2}$ soil extraction.

The results showed that process PM have a toxic effect on lettuce seedling growth and on Vibrio fischeri metabolism. Soil-PM interactions significantly influence PM ecotoxicity and bioavailability; the effect is complex and depends on the duration of ageing. Solubilisation or stabilisation processes with metal speciation changes could be involved. Finally, Microtox and phytotoxicity tests are sensitive and complementary tools for studying process PM ecotoxicity.
\end{abstract}

\section{Introduction}

During the last decade, the proportion of fine and ultrafine particulate matter enriched with metals and metalloids (PM) has increased in the troposphere with the development of recycling activities (Nair et al., 2010) and the use of more effective filters in facilities (Zhang et al., 2005). Thus, sectors of the metal industry, such as secondary smelters that recycle batteries, release fine leadenriched particles into the atmosphere (Batonneau et al., 2004; Uzu et al., 2009). As reported by Cecchi et al. (2008), the different stages of the recycling process (crushing, fusion, reduction and refining) in these facilities generate undesirable by-products enriched with metals and metalloids. These elements have been for the most part classified as Substances of Very High Concern (SVHC) in the European REACH law (Regulation EC 1907/2006 of the European Parliament and of the Council of 18 December 2006). Since then, studies have been devoted to the health implications of PM

* Corresponding author. Address: EcoLab (Laboratoire d'écologie Fonctionnelle) INP-ENSAT, Avenue de l'Agrobiopôle, BP 32607, Auzeville Tolosane, 31326 Castanet-Tolosan, France. Tel.: +33 5343239 03; fax: +33 534323901 .

E-mail address: camille.dumat@ensat.fr (C. Dumat). exposure (Brook et al., 2002; Nel et al., 2006; Sammut, 2007; Polichetti et al., 2009; Perrone et al., 2010).

These fine and ultrafine particles, including nanoparticles, can be transported over long distances in the troposphere (Fernández Espinosa et al., 2002), and due to a high surface/volume ratio (inducing numerous reactive sites), PM could present a greater impact on the biosphere than coarse particles, including atmospheric (Ohmsen, 2001; Batonneau et al., 2004; Nel et al., 2006) and soil contamination (Donisa et al., 2000; Ma et al., 2010a,b). Moreover, carried from the air as fine particles, metals could be easily released in soil solution, then transferred to the surface or sub-surface waters by erosion and run-off. PM transfer from the atmosphere and/or soil to plants (Lin and Xing, 2008; Uzu et al., 2009, 2010), phytotoxicity (Lin and Xing, 2007; Vila et al., 2007), ecotoxicity for microbial communities (Doshi et al., 2008; Strigul et al., 2009) and the impact on the aquatic environment (Moore, 2006; Barrena et al., 2009; Strigul et al., 2009) have recently been considered.

However, most of available studies deal with synthetic manufactured specific species (metal, oxide or sulphate fine particles) such as $\mathrm{TiO}_{2}$ (Warheit et al., 2007), $\mathrm{Ag}, \mathrm{Fe}_{3} \mathrm{O}_{4}$ and $\mathrm{Au}$ (Barrena et al., 2009), $\mathrm{Al}_{2} \mathrm{O}_{3}$ (Yang and Watts, 2005), as well as $\mathrm{Zn}$ and $\mathrm{ZnO}$ (Lin and Xing, 2007). The recent literature has poorly reported works 
using process PM. Moreover, the impact of PM on the terrestrial ecosystem could also depend on soil characteristics (texture, $\mathrm{pH}$, organic matter, etc.) and interactions between soil and particulate matter (complexation, fixation, dissolution, mobility, bioaccessibility, etc.) as reported by Richards et al. (2000). Nevertheless, in many experimental set-ups, the effect of PM on plant development was tested using hydroponic assays with a nutritive solution or wet paper on petri dishes (Lin and Xing, 2007, 2008; Stampoulis et al., 2009; Ma et al., 2010a,b) instead of polluted soils as the substrate for plant growth. These laboratory experiments often involve the use of chemicals such as solvents for PM dispersion in nutritive solutions. In addition, according to Jalali and Khanlari (2008) or Zapusek and Lestan (2009), pollution age could modify the impact of PM.

So, the objective of this work was to study the influence of soilPM interactions and ageing on PM bioavailability and ecotoxicity. Germination tests, growth assays, lead phytoavailability (measured in plant tissues and assessed by $\mathrm{CaCl}_{2}$ extraction) and Microtox analysis were performed in relation to soil types and ageing conditions: (i) PM-spiked soils, (ii) PM-spiked soils aged for 3 months and (iii) long-term historically polluted soil.

\section{Materials and methods}

\subsection{Particulate matter}

\subsubsection{Particle sampling from the smelter}

Process particles were collected from a secondary lead smelter at the Chemical Metal Treatment Company (STCM) which currently recycles batteries. The facility is located in the urban area of Toulouse, in the southwest of France $\left(43^{\circ} 38^{\prime} 12^{\prime \prime} \mathrm{N}, 01^{\circ} 25^{\prime} 34^{\prime \prime} \mathrm{E}\right)$. As described by Uzu et al. (2009), three different sources of particles have been identified in the smelter. Our study focused on the channelled emissions of particles from the rotary furnaces at $1200{ }^{\circ} \mathrm{C}$ because these PM are the finest and are potentially released into the atmosphere where they can become toxic to the environment. Particles were collected in polyethylene bags, transferred in sealed opaque containers and stored at $4{ }^{\circ} \mathrm{C}$ until all experiments.

\subsubsection{Particle characteristics}

The size distribution of the particles was determined by laser granulometric analyses using a Malvern Mastersizer S, which permitted particle size measurements in the range of $0.05-900 \mu \mathrm{m}$. Dust samples were dispersed in alcohol to avoid potential hydrophobic agglomeration and sonicated for $10 \mathrm{~min}$ (Sammut, 2007).

Particles from the channelled emissions of rotary furnaces could be segregated into three size ranges. Expressed as volume fractions, the majority of PM (89\%) were in the $1-100 \mu \mathrm{m}$ range, $7 \%$ were inferior to $1 \mu \mathrm{m}$ (sub-micronic and nanoparticles) and $4 \%$ were superior to $100 \mu \mathrm{m}$ (Uzu et al., in press).

For the present experiments, industrial particles were not sizesegregated in order to retain the real conditions of smelter atmospheric emissions. Heated digestion of the particulate matter was performed with standard acid $\left(\mathrm{HNO}_{3}, \mathrm{HCl}, \mathrm{HF}\right.$, Suprapur, Merck) in a PTFE vessel and filtration (Millex syringe $0.22 \mu \mathrm{m}$ ) was performed as described by Uzu et al. (2009, in press). Elemental total contents were then determined in furnace emissions on an ICP-OES IRIS Intrepid II XXDL. Major elements found in the samples were, by mass: $\mathrm{Pb}(27 \%), \mathrm{O}(15 \%)$ and $\mathrm{S}(7.5 \%)$ with no significant differences according to particle size. Several other secondary metals: $\mathrm{Cd}$ (2.5\%), $\mathrm{Zn}(0.5 \%), \mathrm{Fe}(0.1-0.4 \%)$ and $\mathrm{Sb}(0.1 \%)$ were also present (Uzu et al., in press). The remaining elements to complete $100 \%$ were for the most part chloride, sodium, carbon and other metals such as $\mathrm{Al}, \mathrm{As}, \mathrm{Cu}$ and $\mathrm{Ni}$ recorded as traces. According to Uzu et al. (2009, in press), particles are mainly composed of metallic sulphides, sulphates, oxides and perchlorates; lead speciation was, in decreasing order of abundance: $\mathrm{PbS}, \mathrm{PbSO}_{4}, \mathrm{PbO}^{\mathrm{PbSO}}{ }_{4}$, $\alpha-\mathrm{PbO}$ and $\mathrm{Pb}^{0}$.

\subsection{Soil spiking and ageing processes}

For this experiment, three different soils (annotated soil-1, soil-2 and soil-3) were sampled in the peri-urban zone of Toulouse: soil-1, $43^{\circ} 35^{\prime} 57.24^{\prime \prime} \mathrm{N}, 1^{\circ} 23^{\prime} 41.15^{\prime \prime} \mathrm{E}$; soil-2, 433ำ $50.94^{\prime \prime} \mathrm{N}, 1^{\circ} 30^{\prime} 19.62^{\prime \prime} \mathrm{E}$ and soil-3, 43 $31^{\prime} 36.54^{\prime \prime} \mathrm{N}, 1^{\circ} 30^{\prime} 28.48^{\prime \prime} \mathrm{E}$. They were air dried and sieved through a $2 \mathrm{~mm}$ stainless steel sieve. Acidic digestion and ICP_OES analyses were performed to confirm the absence of trace metallic element contamination. These soils were chosen in view of determining the influence of their characteristics $(\mathrm{pH}$, cation exchange capacity, organic matter, etc.) on the toxicity of industrial micro and sub-micronic particles after deposition. Table 1 summarises the soil properties.

Soils were amended with metallic particles from the smelter emissions with up to three different concentrations of lead: $[\mathrm{Pb}]=825 \pm 15 \mathrm{mg} \mathrm{kg}^{-1} \quad\left(\mathrm{C}_{1}\right) ; \quad[\mathrm{Pb}]=1650 \pm 20 \mathrm{mg} \mathrm{kg}^{-1} \quad\left(\mathrm{C}_{2}\right)$ and $2475 \pm 20 \mathrm{mg} \mathrm{kg}^{-1}\left(\mathrm{C}_{3}\right)$. These corresponds respectively to $1.5,3$ and $4.5 \mathrm{~g}$ of PM added to $500 \mathrm{~g}$ of soil (Uzu et al., 2009). Agitation was performed overnight. Extra boxes containing soils without PM addition were prepared as controls. After spiking and before all the experiments, soils were kept in the dark at $4{ }^{\circ} \mathrm{C}$.

The ageing effect was investigated throughout the comparison between both spiked and historic long-term pollution soils, and by a comparison of soils with various ageing times. Actually, a soil historically polluted by battery recycling emissions $([\mathrm{Pb}]=$ $1650 \pm 20 \mathrm{mg} \mathrm{kg}^{-1}$ ) for 30 years (called soil-4) was also used. Its properties (CEC, granulometry, $\mathrm{pH}$ of soil solution) were summarised in Table 1 and had in common at least one characteristic of the other soils. Soil-4 was a grass-covered topsoil $(0-30 \mathrm{~cm})$ from a meadow, collected just in the front of a lead-recycling plant, already described by Cecchi (2008). $C_{2}$ concentration was chosen as comparable to that of long-term polluted soil-4. For some boxes, with the $\mathrm{C}_{2}$ concentration, ageing was performed in the greenhouse for 3 months: the day/night temperature regime was $23^{\circ} \mathrm{C} / 19^{\circ} \mathrm{C}$ and the relative humidity was maintained at $70 \%$ by weighing the boxes and adding distilled water daily (Lu et al., 2009). According to Lock and Janssen (2002), this process was preferred to the accelerated ageing effect made in the laboratory (seasonal simulation) described by Udovic and Lestan (2009) in view of retaining more realistic conditions of particle deposition.

\subsection{Seed germination and growth assays}

The germination tests and growth assays were performed to investigate PM phytotoxicity (Wang et al., 2001; Ma et al., 2010a,b). Commercial seeds of lettuce (cultivar "Batavia Blonde dorée") were chosen for phytotoxicity tests because lettuce is considered as the most consumed vegetable in the group of leafy vegetables (Křístková et al., 2008). It is almost exclusively used as a fresh vegetable in salads, but some forms are also cooked (Rubatzky and Yamaguchi, 1997; Lebeda et al., 2007). Lettuce is produced commercially in many countries worldwide and is also widely grown as a vegetable in home gardens (Rubatzky and Yamaguchi, 1997). Moreover, this plant is commonly used in recent studies on soil contamination by metals (Alexander et al., 2006; Lin and Xing, 2007; Khan et al., 2008; Uzu et al., 2009).

The germination test was carried out with lettuce seeds that were first immersed in a $10 \%$ sodium hypochloride solution for $10 \mathrm{~min}$ to ensure surface sterility (according to Lin and Xing, 2007). Then, spiked and control soils, $200 \mathrm{~g}$ dry weight equivalent, were placed in plastic pots (Kreysa and Wiesner, 1995; Gong et al., 
Table 1

Properties of the four different soils used for ecotoxicity experiments.

\begin{tabular}{|c|c|c|c|c|c|c|c|c|c|c|}
\hline & \multicolumn{5}{|c|}{ Granulometry (\%) } & \multirow[t]{2}{*}{$\mathrm{pH}$} & \multirow[b]{2}{*}{$\begin{array}{l}\text { Organic matter } \\
\left(\mathrm{g} \mathrm{kg}^{-1}\right)\end{array}$} & \multirow[b]{2}{*}{$\begin{array}{l}\text { Organic carbon } \\
\left(\mathrm{g} \mathrm{kg}^{-1}\right)\end{array}$} & \multirow[b]{2}{*}{$\begin{array}{l}\text { Cation exchange } \\
\text { capacity CEC } \\
\left(\mathrm{cmol}(+) \mathrm{kg}^{-1}\right)\end{array}$} & \multirow[b]{2}{*}{$\begin{array}{l}\text { Limestone } \\
\mathrm{CaCO} 3 \\
\left(\mathrm{~g} \mathrm{~kg}^{-1}\right)\end{array}$} \\
\hline & Clay & Thin silt & Rough silt & Thin sand & Rough sand & & & & & \\
\hline Soil-1 & 13.3 & 24.8 & 23.5 & 22.5 & 15.9 & 6.5 & 44.7 & 26 & 12.3 & 0 \\
\hline Soil-2 & 22.8 & 15.8 & 10.7 & 15.8 & 34.9 & 6.41 & 10.1 & 5.86 & 10.1 & $<1$ \\
\hline Soil-3 & 19.5 & 15.4 & 23.6 & 23.8 & 17.7 & 8.39 & 12.5 & 7.2 & 8.88 & 98 \\
\hline Soil-4 & 23.9 & 27.3 & 28.1 & 9.8 & 10.9 & 7.9 & 8.7 & 3.8 & 15.85 & 2 \\
\hline
\end{tabular}

2001). Each pot was $8 \mathrm{~cm}$ (top) in diameter and $7 \mathrm{~cm}$ in height with some drain holes on the bottom. Germination was assessed using three replicates of each kind of soil (spiked, aged, control) and concentration in the PM condition. The bioassay was performed in a growth chamber at $23-18{ }^{\circ} \mathrm{C}$ as the day-night temperatures. Germination was determined by visual seedling emergence (Gong et al., 2001) and recorded after $8 \mathrm{~d}$ in exposed seeds and controls (Vila et al., 2007). Protuberance of radicals was also taken as the initiation of germination (Chaudhuri, 2002).

After germination recording, only three seedlings of the most uniform plants were kept in each pot to perform growth assays (Gong et al., 2001). Length (root and shoot elongation), fresh and dry weight of roots and shoots and the number of leaves were measured after $17 \mathrm{~d}$ of growth. Shoot height was measured from the shoot base to the top of the longest leaf and root length was measured from the root-shoot junction to the top of the longest root (Liu et al., 2005). Fresh biomass was weighed immediately whereas the dry biomass was measured after oven drying (Gong et al., 2001) at $40 \pm 2{ }^{\circ} \mathrm{C}$ for $72 \mathrm{~h}$. Experiments were done in triplicate.

As described by Tiquia et al. (1996) and Barrena et al. (2009), phytotoxicity was then expressed by two soil contamination indicators: germination index $(G I)$ (which involves relative seed germination) and relative root elongation $(E)$.

$$
\begin{aligned}
E= & (\text { Mean root length with } \mathrm{PM} / \text { Mean root length with control }) \\
& \times 100
\end{aligned}
$$$$
\mathrm{GI}=(\text { Relative seed germination } \times E) / 100
$$

With : Relative seed germination

$=($ seeds germinated with $\mathrm{PM} /$ seeds germinated with control $)$ $\times 100$

The germination index was calculated by comparison to controls that were assimilated for each type of soil to a germination reference (control index: 100\%).

\subsection{Lead phytoavailability determination}

Lead phytoavailability in the different soils (before and after ageing and in the historically polluted soil) was determined with the $0.01 \mathrm{M} \mathrm{CaCl}_{2}$ extraction procedure described by Houba et al. (1996) and Uzu et al. (2009). The metal fraction extracted by $\mathrm{CaCl}_{2}$ gives an indication of metal concentration in a soil solution and therefore of metal solubility (Meers et al., 2007). Thirty millilitres of $0.01 \mathrm{M} \mathrm{CaCl}_{2}$ solution was mixed with $3 \mathrm{~g}$ of soil ( $1: 10$ solid solution ratio) in $50 \mathrm{~mL}$ polypropylene centrifugation tubes placed on a shaker table (Heidolph promax 1020) at 50 oscillations $\mathrm{min}^{-1}$ for $2 \mathrm{~h}, 20^{\circ} \mathrm{C}$. After extraction, tubes were centrifuged at $10000 \mathrm{~g}$ for $30 \mathrm{~min}$. The supernatant liquid was then filtered, acidified to $2 \%$ with distilled $\mathrm{HNO}_{3}\left(15 \mathrm{M}\right.$, suprapur 99.9\%) and stored at $4{ }^{\circ} \mathrm{C}$ before analysis. Extracted metal concentrations were determined by ICP-OES (IRIS Intrepid II XXDL).

\subsection{Lead transfer to lettuce shoots and roots}

Roots and shoots were collected $17 \mathrm{~d}$ after the germination test for all soil conditions. Lead (the main metal in process PM) accumulation was analysed separately for the different plant tissues after oven-drying at $40{ }^{\circ} \mathrm{C}$ for $48 \mathrm{~h}$. Fresh and dried biomasses were determined. Roots and shoots were mineralised in a 1:1 mixture of $\mathrm{HNO}_{3}$ and $\mathrm{H}_{2} \mathrm{O}_{2}$ at $80{ }^{\circ} \mathrm{C}$ for $4 \mathrm{~h}$ according to Uzu et al. (2009). Lead concentrations in plant samples were finally measured by ICP-OES (IRIS Intrepid II XXDL). The accuracy of acidic digestion and analytical procedures was checked using Virginia tobacco leaves (CTAVTL-2, ICHTJ) as reference.

\subsection{Microtox analysis}

First used to assess acute ecotoxicity of metals in aquatic media (De Zwart and Slooff, 1983), solid-phase Microtox test is now currently used to evaluate the toxicity of contaminated soils or sediments (Rink et al., 2002; Sheehan et al., 2003; Robidoux et al., 2004; Loureiro et al., 2005; Doshi et al., 2008; Barrena et al., 2009).

The Microtox test measures the decrease in light emitted by the bioluminescent bacteria Vibrio fischeri. Toxicity is reported as the effective concentration $\mathrm{EC}_{50}$, which is the concentration of a contaminant that produces a $50 \%$ reduction in light emission. $\mathrm{EC}_{50}$ was measured after 5 and $15 \mathrm{~min}$ of exposure (Barrena et al., 2009). This acute test is used to determine the potential toxicity of a liquid or solid phase sample on bacteria, and by extension, toxicity on aquatic or soil microbial activity. Soil contamination can be one path for streams and groundwater contamination (Loureiro et al., 2005). Moreover, atmospheric fallout enriched in metallic particles could directly pollute surface and sub-surface waters or be transferred from the soil by infiltration or leaching processes. Therefore, the two tests (liquid and solid phases) were performed.

In view of evaluating PM toxicity in solution, the Microtox 81.9\% Basic Test with the instrument MICROTOX M 500 purchased from R-biopharm (France) was used. Suspensions of industrial particles were prepared in deionised water with sodium chloride (2\%) as mentioned in the manufacturer's instructions. Agitation was performed with a glass rod and $15 \mathrm{~min}$ on plate shaker to avoid particulate matter destruction by sonication or metal adsorption onto magnetic bars. Lyophilised bacteria were rehydrated with the included reconstitution solution just prior to performing the test (Strigul et al., 2009). Nine concentrations of PM suspensions obtained by a sequence of $1: 1$ dilutions ranging from $6.4 \times 10^{-4}$ to $0.164 \mathrm{~g} \mathrm{~L}^{-1}$ were tested.

The toxicity of various PM-spiked soil suspensions (soil-1, soil-2 and soil-3) was determined by the solid-phase test at different concentrations (Doshi et al., 2008). Three grams of PM-spiked soils at $[\mathrm{Pb}]=1650 \pm 20 \mathrm{mg} \mathrm{kg}^{-1}\left(\mathrm{C}_{2}\right)$ were dispersed in $15 \mathrm{~mL} \mathrm{DI}, 3 \%$ $\mathrm{NaCl}$. After $15 \mathrm{~min}$ of shaking, dilutions were made in order to test toxicity in a range from 197 to $0.048 \mathrm{~g} \mathrm{~L}^{-1}$ of soil suspensions. Each 
Microtox test consisted of two controls and several toxicant soil concentrations each in duplicate. Every test was performed in triplicate.

\subsection{Statistical analysis}

All tests were performed in triplicate and the results are presented as mean \pm SD (standard deviation). The statistical significance of values was checked using a one-way analysis of variance ANOVA with the LSD Fisher post-hoc test using the Statistica 9.0 package software. Each effect was compared to its corresponding control (with an uncontaminated soil). Statistical difference was accepted when the probability of the result assuming the null hypothesis $(p)$ was less than 0.05 .

\section{Results}

\subsection{Phytotoxicity evaluation}

PM phytotoxicity was evaluated by studying complementary parameters. Chronologically, the first observations were made on seed germination, then we report the results on root elongation and leaf growth. The results focused on the impact of: (i) PM concentrations, (ii) soil-particle interactions as a function of soil type and (iii) the effect of ageing on germination and elongation assays.

\subsubsection{Effects of PM concentrations and soil-PM interactions}

For germination data, a trend was observed, but it was not statistically significant. The germination index decreased when PM concentration increased (results not shown). Then, as shown in Fig. 1 (giving the relative root elongation index), root length significantly decreased when PM concentration increased (ANOVA, $p<0.05)$. A significant dose response was observed for soil-1 and soil-3.

According to Fig. 2, whatever the kind of soil, PM had an impact on shoot elongation and biomass. The development of thinner and shorter shoots was induced by PM exposure compared to controls (ANOVA, $p<0.05$ ). Contrary to the root elongation results, there was not a clear dose response effect for shoots (Fig. 2). Finally, leaf number and colouration were not affected by PM (results not shown).

No significant difference was observed between the three control soils (ANOVA, $p>0.05$ ): they had the same behaviour regardless of the phytotoxicity marker (germination, root and shoot growth). Nevertheless, when these soils were spiked, they ex-

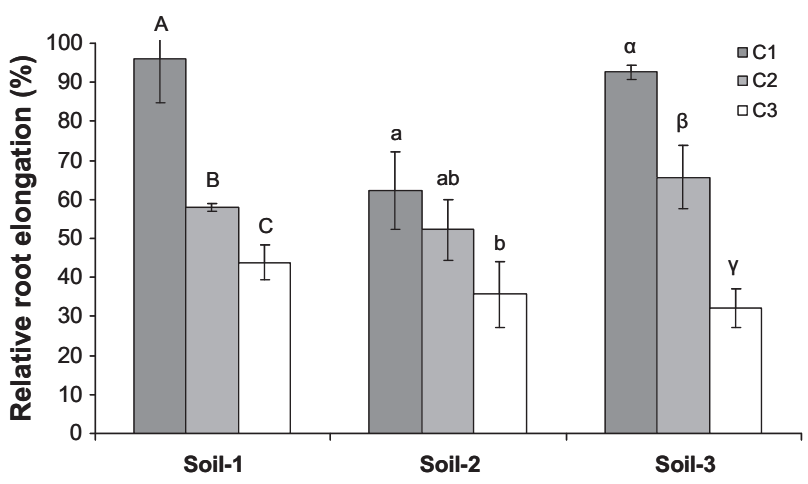

Fig. 1. Influence of PM concentration and soil properties on root growing. Results are expressed as relative root elongation (\% relative to controls). $C_{1}$ : $[\mathrm{Pb}]=825 \pm 15 \mathrm{mg} \mathrm{kg}^{-1} ; \mathrm{C}_{2}$ : $[\mathrm{Pb}]=1650 \pm 20 \mathrm{mg} \mathrm{kg}^{-1}$ and $\mathrm{C}_{3}: 2475 \pm 20 \mathrm{mg} \mathrm{kg}^{-1}$. Values are given as mean \pm SD (standard deviation) of triplicate samples with three seedlings each. pressed, globally, the same responses in observed effects but with different amplitude (see Figs. 1 and 2).

\subsubsection{Ageing effect}

In view of evaluating the soil ageing effect on PM ecotoxicity, germination and elongation tests were performed at $\mathrm{C}_{2}([\mathrm{~Pb}]=$ $1650 \pm 20 \mathrm{mg} \mathrm{kg}^{-1}$ ) by comparison with the controls for each type of soil.

The 3 month ageing period had a significant impact on the elongation parameter. Fig. 3 shows a representation of root elongation after $17 \mathrm{~d}$ in the different contaminated soils, in comparison to controls. Roots grown in aged spiked soil were shorter than roots grown in non-aged spiked roots ( $p<0.05$ for soil-2 and soil-3). Actually, for the same PM concentration ([Pb] $=1650 \pm 20 \mathrm{mg}$ $\mathrm{kg}^{-1}$ ), root growth was significantly slowed down in spiked, aged soil-2 and soil-3. However, the long-term polluted soil (soil-4) was less phytotoxic; root length in this polluted soil was not significantly different to the three controls (ANOVA, Fisher test, $p>0.05$ ).

Fig. 4 shows the results of lead accumulation in plant shoots (A) and roots (B) for the soil-3 ageing experiment. In fresh and aged spiked soils, lead concentrations were significantly different to controls. The ageing process on spiked soil increased lead transfer to roots and its translocation to shoots (see Fig. $4, p<0.05$ ). The same results were observed for the other studied soil-1 and soil-2 (not shown). In the long-term polluted soil, lead accumulation in roots and shoots was not as high as in spiked soils, and relatively close to control shoots. In the same way, mean lead concentrations extracted by $\mathrm{CaCl}_{2}$ were, respectively, $4.2 \pm 0.4,5.1 \pm 0.2$ and $3.1 \pm 0.3 \mathrm{mg} \mathrm{Pb} \mathrm{kg}^{-1}$ of spiked soil-3, aged spiked soil-3 and longterm polluted soil.

\subsection{Effects on microbial activity: bioluminescent test}

\subsubsection{PM suspensions: Microtox $81.9 \%$ basic test}

Fig. 5 shows the results of microbial toxicity in solution. Longer exposure times were associated with lower $\mathrm{EC}_{50}$, suggesting that industrial particles are toxic to microorganisms.

\subsubsection{Solid-phase test and ageing effect}

Table 2 summarises the $\mathrm{EC}_{50}$ data for controls, spiked soils and aged spiked soils for each kind of soil suspension. All the data dealing with the effect of PM-spiked soils on bioluminescence inhibition in relation to the soil suspension concentrations $\left(\mathrm{mg} \mathrm{L}^{-1}\right)$ are given in Supplemental material (Figs. S1, S2 and S3). The results were almost the same after $5 \mathrm{~min}$ or $15 \mathrm{~min}$, so the table only reports the 5 min results. For each kind of soil, Table 2 shows that the PM-amended soils had an effect on light output at a lower concentration than the control soil $\left(\mathrm{EC}_{50}\right.$ obtained for a lower concentration of process PM). This representation takes into account the potential loss of luminescence due to the turbidity of soil suspensions, and the toxicity already present in soil before spiking. Soil-3 (without PM) was the most toxic, and the $\mathrm{EC}_{50}$ of the control was the lowest at $12.7 \mathrm{~g} \mathrm{~L}^{-1}$ of the soil suspension (equivalent to $76.2 \mathrm{mg} \mathrm{L}^{-1}$ of $\mathrm{PM}$ or $20.9 \mathrm{mg} \mathrm{L}^{-1}$ of $\mathrm{Pb}$ in suspensions).

Moreover, by comparison to the spiked soils with the same contamination level, ageing influenced PM toxicity (Table 2 and Supplemental material). The toxicity of soil suspensions was increased after a 3-month ageing period in the greenhouse, $\mathrm{EC}_{50}=169 \mathrm{mg} \mathrm{L}^{-1}$ instead of $339 \mathrm{mg} \mathrm{L}^{-1}$ for soil-1, $\mathrm{EC}_{50}=$ $142 \mathrm{mg} \mathrm{L}^{-1}$ instead of $689 \mathrm{mg} \mathrm{L}^{-1}$ for soil-2 and $\mathrm{EC}_{50}=676 \mathrm{mg} \mathrm{L}^{-1}$ instead of $3440 \mathrm{mg} \mathrm{L}^{-1}$ for soil-3. The ageing effect seemed to be more important for soil-3 (and soil-2) than for soil-1 (higher difference in the $\mathrm{EC}_{50}$ ).

Finally, the long-term polluted soil (soil-4) was tested in the Microtox assay and its $\mathrm{EC}_{50}$ was determined to be $\mathrm{EC}_{50}=22.4 \mathrm{~g} \mathrm{~L}^{-1}$ 

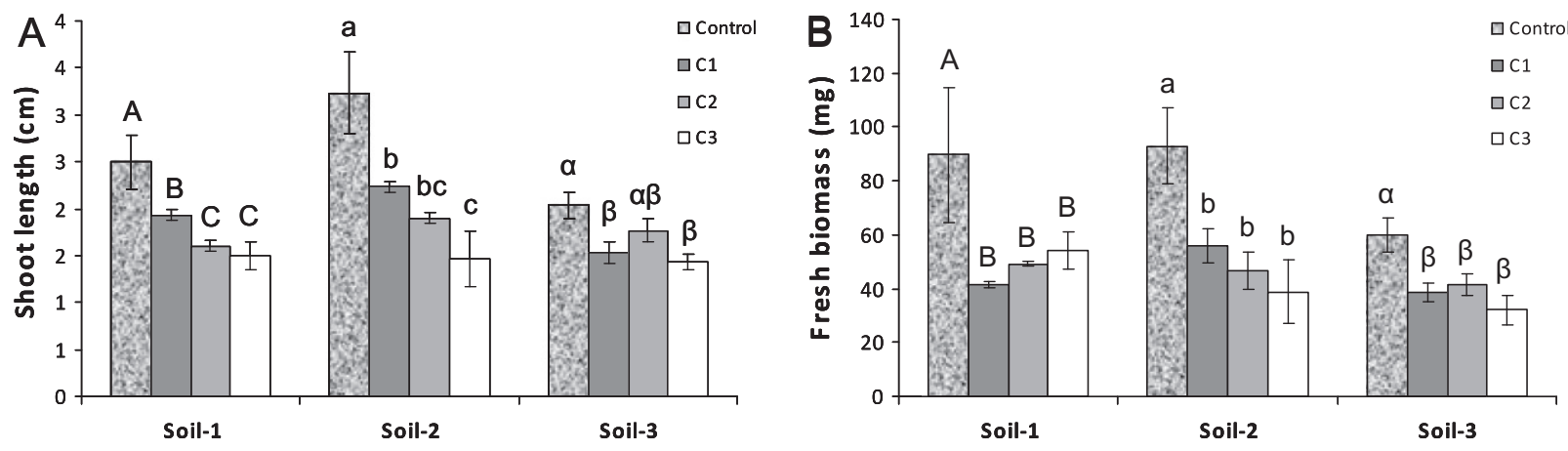

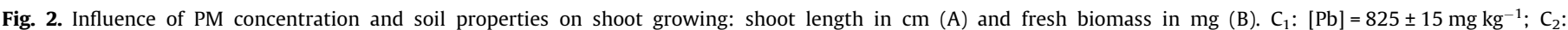
$[\mathrm{Pb}]=1650 \pm 20 \mathrm{mg} \mathrm{kg}^{-1}$ and $\mathrm{C}_{3}: 2475 \pm 20 \mathrm{mg} \mathrm{kg}^{-1}$. Values are given as mean $\pm \mathrm{SD}$ (standard deviation) of triplicate samples with three seedlings each.

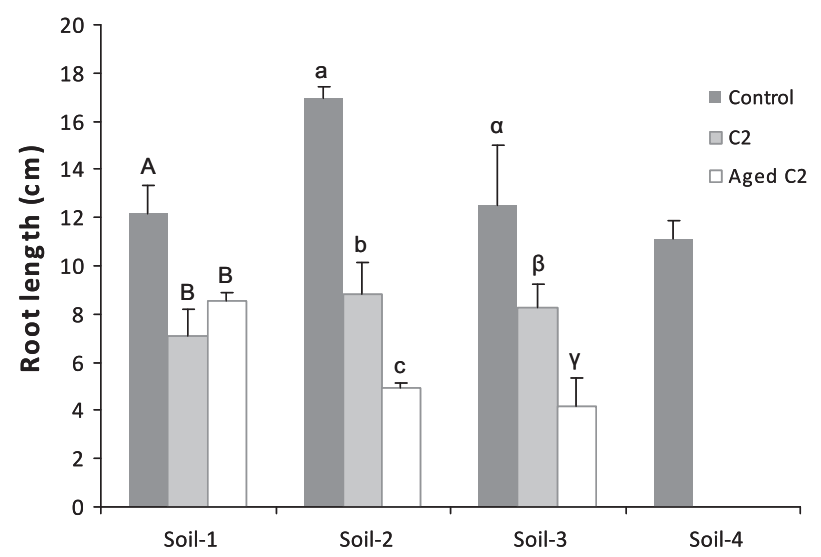

Fig. 3. Effect of ageing procedure on root elongation as a biomarker of PM phytotoxicity. Results are expressed according to the different soils on root length $\left(\mathrm{C}_{2}:[\mathrm{Pb}]=1650 \pm 20 \mathrm{mg} \mathrm{kg}^{-1}\right)$. Values are given as mean $\pm \mathrm{SD}$ (standard deviation) of triplicate samples with three seedlings each.

after $5 \mathrm{~min}$ and $20 \mathrm{~g} \mathrm{~L}^{-1}$ after $15 \mathrm{~min}$. These values are very close to those obtained for the control soils (the $\mathrm{EC}_{50}$ was even higher than in soil-3). Therefore, the toxicity of soil-4 for $V$. fischeri was low.

\section{Discussion}

\subsection{PM ecotoxicity assessment}

PM had an impact on plant growth. Roots are in direct contact with PM during their elongation and not protected against the toxic effects of soil pollutants. Previous studies on manufactured PM concluded that they have an inhibitive effect on root elongation (Yang and Watts, 2005; Lin and Xing, 2007; Lee et al., 2008; Stampoulis et al., 2009). Process PM emitted by the lead recycling plant appears to have had a similar impact in relation to metal accumulation. Moreover, the study on lettuce shoots supported the same conclusions. Thus, shoot parameters (elongation and biomass) may be useful to compare toxicity effects after seed exposure to process particles. Nevertheless, our first results have shown that, even if a reduction trend could be described for the three soils, according to Ma et al. (2010a,b) (working on synthesised oxide nanoparticles), lettuce germination was not affected by metal soil pollution. Lin and Xing (2007) explained this phenomenon by the protection of the lettuce seed coat against external pollutant penetration, while Wierzbicka and Obidzinska (1998) attributed this to selective permeability of the seed coat. So, root elongation can be more sensitive than germination index for this type of hazardous material contamination, especially when the toxicity directly affects root development, as reported by Barrena et al. (2009).
Furthermore, process PM and PM-spiked soil suspensions had a significant impact on bacteria, as a light output decrease was observed in the Microtox test. A battery of ecotoxicological tests had already shown that synthesised thin particles are toxic to aquatic organisms, both unicellular as bacteria and animals (Nowack and Bucheli, 2007). Nevertheless, among the few studies concerning metallic PM, the conclusions strongly differ. Actually, Barrena et al. (2009) showed that thin particles of Ag, Fe or Au in suspensions did not have any effect on the bioluminescence test. In contrast, Strigul et al. (2009), working with boron nanoparticles in suspension, reported an effect on bacteria metabolism and suggested that the Microtox test is efficient for evaluating the impact of manufactured particles on water quality.

Incidentally, the ecotoxicity results on $V$. fischeri bacteria exposed to PM were coherent with the phytotoxicity results. The correlation coefficients between root length and the Microtox assay data were calculated; the $R^{2}$ values are, respectively, $0.92,0.90$ and 0.92 for soil-1, soil- 2 and soil-3. These observations suggest that there is a clear relationship between the performed tests. Whatever ecotoxicity bioassay used, the acute toxicity of PM was highlighted, certainly due to their large surface area and composition (Ma et al., 2010a,b). Moreover, a PM dose-response effect was observed, and the Microtox and phytotoxicity tests seemed therefore to be sensitive and complementary tools for studying process PM ecotoxicity.

\subsection{Impact of soil-PM interaction on bioavailability and ecotoxicity}

The results of the Microtox solid-phase test are expressed as the quantity of spiked soil suspensions introduced in bacteria medium (mg of soil per litre). However, by calculating the quantity of PM added in amended soils, results could be expressed as mg of PM introduced per litre. The $\mathrm{EC}_{50}$ values were, respectively, 2.2, 4.1 and $20.6 \mathrm{mg} \mathrm{L}^{-1}$ of PM in soil-1, soil-2 and soil-3. So, there was a difference in the bacterial response between the PM suspensions $\left(\mathrm{EC}_{50}=68.7 \mathrm{mg} \mathrm{L}^{-1}\right.$ of PM $)$ and the PM-amended soil suspensions. These results suggest that PM ecotoxicity was increased by soilPM interactions. The same trend was observed by Doshi et al. (2008) working on aluminium manufactured PM. Moreover, Uzu et al. (2009) have already reported that in spiked soils, $\mathrm{CaCl}_{2}$ metal exchangeability is ten times higher than in PM, suggesting these PM-soil interactions. Actually, according to Birkefeld et al. (2007), who studied in situ transformation of lead particles from a smelter in several soils, solubility is strongly dependent on soil characteristics. For example, working on organic vs. inorganic fertilisers in reducing metal phytoavailability, Singh et al. (2010) reported that organic matter contents had an impact on metal phytoavailability and transfer. However, our soils differ by several parameters such as texture, clay content, $\mathrm{pH}$, lime content, organic 


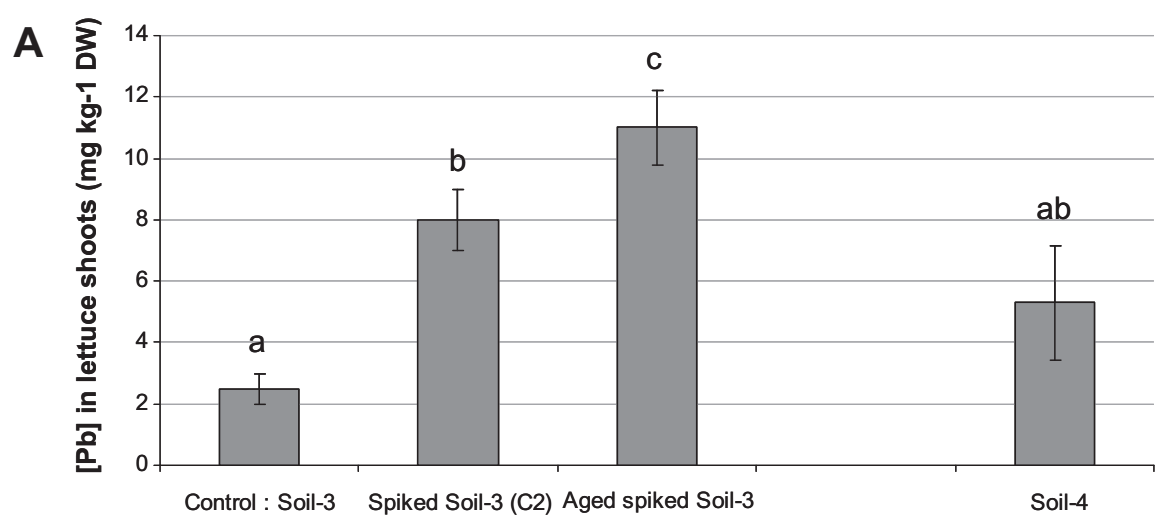

(C2)

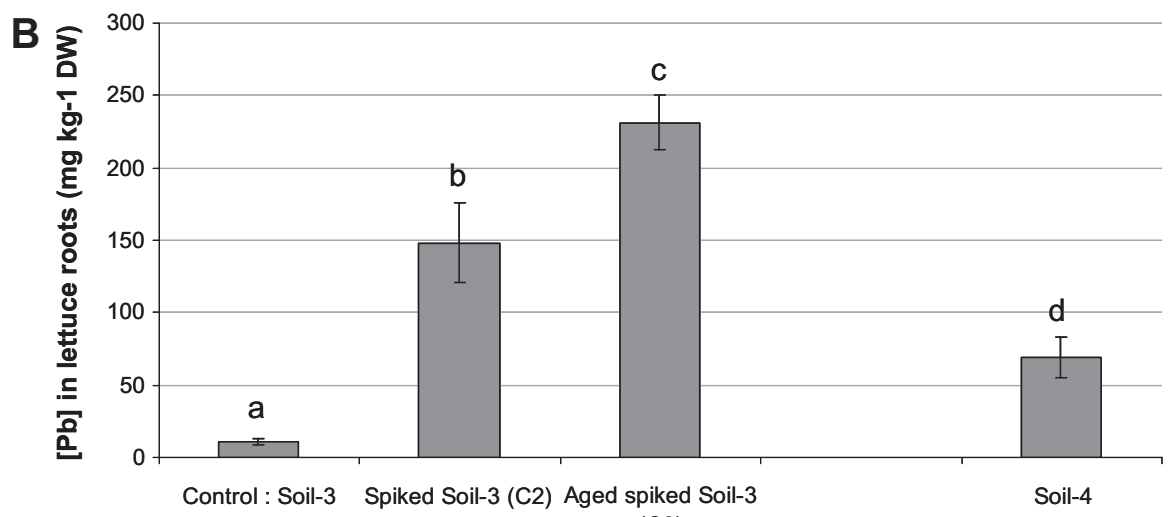

(C2)

Fig. 4. Lead concentrations in lettuce shoots (A) and roots (B) in $\mathrm{mg} \mathrm{kg}^{-1}$ of dry weight, in different spiked or aged soils after $17 \mathrm{~d}$. Results are expressed as the mean of three replicates $( \pm S D)$ for a lead concentration in soils at $1650 \pm 20 \mathrm{mg} \mathrm{kg}^{-1}$.

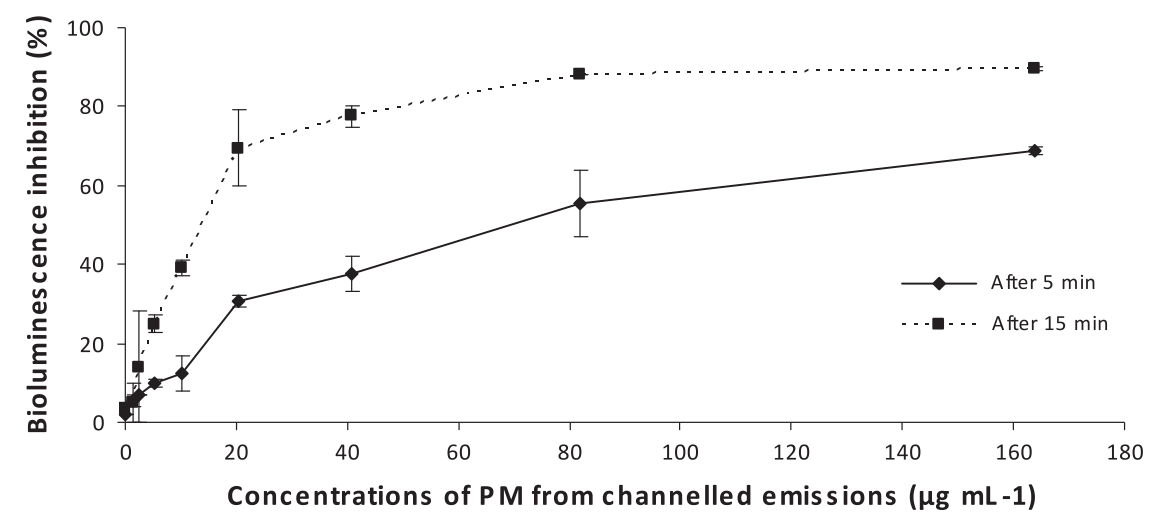

Fig. 5. Effect of PM concentrations on bioluminescent inhibition (Microtox 81.9\% Basic Test).

Table 2

Effect of ageing procedure on toxicity for Vibrio fisheri after 5 min of contact, in relation with the kind of spiked soil. Effective concentration $\left(\mathrm{EC}_{50}\right)$ values are given in $\mathrm{mg} \mathrm{L}^{-1}$.

\begin{tabular}{llll}
\hline & \multicolumn{3}{l}{$\mathrm{EC}_{50}\left(\mathrm{mg} \mathrm{L}^{-1}\right)$ of soil suspensions } \\
\cline { 2 - 4 } & Controls & Spiked soils $\left(\mathrm{C}_{2}\right)$ & Aged spiked soils $\left(\mathrm{C}_{2}\right)$ \\
\hline Soil-1 & $>200000$ & 339 & 169 \\
Soil-2 & 38600 & 689 & 142 \\
Soil-3 & 12700 & 3440 & 676
\end{tabular}

Notes: $\mathrm{C}_{2}:[\mathrm{Pb}]=1650 \pm 20 \mathrm{mg} \mathrm{kg}^{-1}$ impact evaluation is performed by measuring light output decrease. Toxicity is reported as effective concentration $\mathrm{EC}_{50}$ for each soil suspension. matter; the influence of even one property on soil-PM interactions is therefore too complex to highlight.

Nevertheless, the three soils do not respond in the same way according to bioluminescence inhibition. Their biogeochemistry could be an explanation. Actually, soil-3 (as a control), was characterised by a high content of limestone $\left(98 \mathrm{~g} \mathrm{~kg}^{-1}\right.$, Table 1$)$ and was the most toxic soil for $V$. fischeri (its $\mathrm{EC}_{50}$ control soil was the lowest). However, after spiking, it became less toxic to bacteria compared to the other PM-amended soils (its $\mathrm{EC}_{50}$ spiked soil was the highest). Thus, as already noted by Birkefeld et al. (2007), lead oxide particles incubated in calcareous sand can be covered by a crust of lead carbonate within 2 months. This crust could protect lead oxide particles against further weathering and could then decrease toxicity. 


\subsection{Influence of ageing on soil ecotoxicity}

The results showed that the ageing period strongly influenced PM-spiked soil ecotoxicity (Figs. 3 and 4 and S1, S2 and S3). Actually, during ageing processes, metal solubilisation, availability and toxicity can be modified (Richards et al., 2000; Jalali and Khanlari, 2008; Zapusek and Lestan, 2009). Mixed with soil for several months, particle solubility could therefore have changed as suggested by the increase of lead transfer in lettuce tissues and $\mathrm{CaCl}_{2}$ exchangeability after the ageing period, and their ecotoxicity could have been modified (Uzu et al., 2009). As shown by Lock and Janssen (2001), metal bioavailability is largely influenced by the ageing period. Moreover, as reported by Ma et al. (2010a,b), small sized particles are prone to aggregation in the aqueous phase, which may change their bioavailability and toxicity over time. PM dissolution, phase transformation and speciation are sensitive to soil geochemistry (Birkefeld et al., 2007; Uzu et al., 2009). The dissolution of particulate matter in the soil solution during the ageing processes could release several metals (as ionic compounds). Thus, this phenomenon could be an explanation of the increase in the toxicity of process particles (Fig. 3 and Supplementary materials) and lead accumulation in lettuce roots and shoots with the ageing period (Fig. 4).

However, as already noted by Lin and Xing (2008), the phytotoxicity of metallic particles cannot be explained only by the dissolution of metallic ions. The toxicity may come from ultrafine particle aggregation and adhesion on the root surface and their penetration into epidermal and cortical cells until damage is caused to the vascular cells. In the case of bacteria, the cell-PM interaction is size-dependent (Morones et al., 2005) and seems to depend also on the shape of the PM (Pal et al., 2007). For example, Nowack and Bucheli (2007) reported that nano-Ag appeared to be significantly more toxic than $\mathrm{Ag}^{2+}$ ions towards Escherichia coli. Therefore, we can suppose that ageing processes (for 3 months) combine these two effects: metallic ion dissolution in the soil solution and particle aggregation and penetration into plant tissues or bacterial cells. Toxicity was more acute in aged spiked soils. Only soil-1, characterised by its high organic matter, was not significantly more toxic after the ageing process, by comparison to the other soils (Fig. 3). Actually, several authors had previously reported this effect of organic matter on metal release, transfer and toxicity in soils (Yin et al., 2002; Inaba and Takenaka, 2005; Bermudez et al., 2010). Organic ligands could modify both metal uptake and phytotoxicity by changing free metal ion concentrations through speciation (Shahid et al., 2011).

However, the historically long-term (30 years) polluted soil was less toxic than the different spiked soils. This could be explained by long-term stabilisation processes involving strongly stabilised lead compound formation like pyromorphite and lead-enriched clay minerals (Dumat et al., 2001; Cecchi et al., 2008). Its lower toxicity and lead exchangeable fraction compared to spiked soil-1, soil-2 and soil-3 may have been due to its lower concentration of released toxicants (especially $\mathrm{Pb}$ ). Because of long-term chemical processes, metal bioavailability in field soils decreases over time (Lock and Janssen, 2003a,b). For example, variations in the relative molecular size fractions present within the dissolved organic carbon (DOC) pool as a result of increased time and temperature may influence the proportion of element-DOC complexes and their behaviour in soils (Martínez et al., 2003). Temporal changes, climate variations and plant cultivation on metal-polluted soils could accelerate metal speciation transformations and then decrease their bioavailability (Fendorf et al, 2004; Buekers et al., 2007). Actually, by producing exudates, plants can modify metal speciation and their behaviour in soil, especially in the rhizosphere (Chaignon and Hinsinger, 2003; Uzu et al., 2009).

Thus, as reported by Lock and Janssen (2003a,b), the use of spiked soils in toxicity assays can result in an overestimation of metal effects, especially at high $\mathrm{pH}$. Therefore, the perspectives of this work could inform the testing of different ageing processes and their effect on toxicity evaluations with the root elongation assay and the Microtox test.

\section{Conclusions and perspectives}

This study focused on the impact of process waste metallic ultrafine particles, not intentionally emitted into the environment, on plants and microorganisms. It deals with an environmental risk assessment of contamination by atmospheric fallouts from lead recycling plants.

Due to their small size and composition, these industrial ultrafine particles are toxic for ecosystems. They reduce root and shoot elongation for plants and disturb $V$. fischeri metabolism. The ecotoxicity of these process particles was increased by short-term interactions with soils. However, after long-term exposure, ecotoxicity decreases with metal bioavailability in soils.

The interest of using combined toxicity tests (the plant elongation assay and the Microtox test) to appreciate the impact of PM on ecosystems was demonstrated. Lettuce germination was not significantly affected by metal soil pollution, suggesting that this indicator was not sensitive enough for this kind of pollutant.

Further studies could be performed in view of obtaining a range of references on the responses of ecosystems exposed to metallic particles from different sources, with different sizes and speciation, from different industrial processes, especially for the Microtox test for which there are currently only a few data available. Moreover, different ageing processes and times should be compared in view of obtaining the best simulation of stabilisation processes.

\section{Acknowledgments}

We gratefully acknowledge ADEME, the French Agency of the Environment and Energy as well as the STCM Chemical Metal Treatment Company for their technical help in experimental setup and for their financial support.

\section{Appendix A. Supplementary material}

Supplementary data associated with this article can be found, in the online version, at doi:10.1016/j.chemosphere.2011.07.059.

\section{References}

Alexander, P.D., Alloway, B.J., Dourado, A.M., 2006. Genotypic variations in the accumulation of $\mathrm{Cd}, \mathrm{Cu}, \mathrm{Pb}$ and $\mathrm{Zn}$ exhibited by six commonly grown vegetables. Environ. Pollut. 144 (3), 736-745.

Barrena, R., Casals, E., Colón, J., Font, X., Sánchez, A., Puntes, V., 2009. Evaluation of the ecotoxicity of model nanoparticles. Chemosphere 75, 850-857.

Batonneau, Y., Bremard, C., Gengembre, L., Laureyns, J., Le Maguer, A., Le Maguer, D., Perdrix, E., Sobanska, S., 2004. Speciation of PM10 sources of airborne nonferrous metals within the $3-\mathrm{km}$ zone of lead/zinc smelters. Environ. Sci. Technol. 38, 5281-5289.

Bermudez, G.M.A., Moreno, M., Invernizzi, R., Plá, R., Pignata, M.L., 2010. Heavy metal pollution in topsoils near a cement plant: The role of organic matter and distance to the source to predict total and $\mathrm{HCl}$-extracted heavy metal concentrations. Chemosphere 78, 375-381.

Birkefeld, A., Schulin, R., Nowack, B., 2007. In situ transformations of fine lead oxide particles in different soils. Environ. Pollut. 145, 554-561.

Brook, R.D., Brook, J.R., Urch, B., Vincent, R., Rajagopalan, S., Silverman, F., 2002 Inhalation of fine particulate air pollution and ozone causes acute arterial vasoconstriction in healthy adults. Circulation 105, 1534-1536.

Buekers, J., Van Laer, L., Amery, F., Van Buggenhout, S., Maes, A., Smolders, E., 2007. Role of soil constituents in fixation of soluble $\mathrm{Zn}, \mathrm{Cu}, \mathrm{Ni}$ and $\mathrm{Cd}$ added to soils. Eur. J. Soil. Sci. 58, 1514-1524.

Cecchi, M., 2008. Devenir du plomb dans le système sol-plante. Cas d'un sol contaminé par une usine de recyclage du plomb et de deux plantes potagères (Fève et Tomate). Thèse de doctorat de l'Institut National Polytechnique de Toulouse, INP-ENSAT, 226 pp. 
Cecchi, M., Dumat, C., Alric, A., Felix-Faure, B., Pradere, P., Guiresse, M., 2008. Multimetal contamination of a calcic cambisol by fallout from a lead-recycling plant. Geoderma 144, 287-298.

Chaignon, V., Hinsinger, P., 2003. A biotest for evaluating copper bioavailability to plants in a contaminated soil. J. Environ. Qual. 32, 824-833.

Chaudhuri, S.K., 2002. A simple and reliable method to detect gamma irradiated lentil (Lens culinaris Medik.) seeds by germination efficiency and seedling growth test. Rad. Phys. Chem. 64, 131-136.

De Zwart, D., Slooff, W., 1983. The Microtox as an alternative assay in the acute toxicity assessment of water pollutants. Aquat. Toxicol. 4, 129-138.

Donisa, C., Mocanu, R., Steinnes, E., Vasu, A., 2000. Heavy metal pollution by atmospheric transport in natural soils from the northern part of eastern Carpathians. Water, Air, Soil Pollut. 120, 347-358.

Doshi, R., Washington, B., Christodoulatos, C., O’Connor, G., Wazne, 2008. Nanoaluminium: transport through sand columns and environmental effects on plant and soil communities. Environ. Res. 106, 296-303.

Dumat, C., Chiquet, A., Gooddy, D., Aubry, E., Morin, G., Juillot, F., Benedetti, M.F., 2001. Metal ion geochemistry in smelter impacted soils and soil solutions. Bull. Soc. Géol. Fr. 172, 539-548.

Fendorf, S., LaForce, M.J., Li, G.C., 2004. Temporal changes in soil partitioning and bioavailability of arenic, chromium, and lead. J. Environ. Qual. 33, 20492055.

Fernández Espinosa, A.J., Ternero Rodríguez, M., Barragán de la Rosa, F.J., Jiménez Sánchez, J.C., 2002. A chemical speciation of trace metals for fine urban particles. Atmos. Environ. 36, 773-780.

Gong, B., Wilke, M., Strozzi, E., Fleischmann, S., 2001. Evaluation and refinement of a continuous seed germination and early seedling growth test for the use in the ecotoxicological assessment of soils. Chemosphere 44, 491-500.

Houba, V.J.G., Lexmond, T.M., Novozamsky, I., van der Lee, J.J., 1996. State of the art and future developments in soil analysis for bioavailability assessment. Sci. Total Environ. 178, 21-28.

Inaba, S., Takenaka, C., 2005. Effects of dissolved organic matter on toxicity and bioavailability of copper for lettuce sprouts. Environ. Int. 31, 603-608.

Jalali, M., Khanlari, Z.V., 2008. Effect of aging process on the fractionation of heavy metals in some calcareous soils of Iran. Geoderma 143, 26-40.

Khan, S., Aijun, L., Zhang, S.Z., Hu, Q.H., Zhu, Y.G., 2008. Accumulation of polycyclic aromatic hydrocarbons and heavy metals in lettuce grown in the soils contaminated with long-term waste water irrigation. J. Hazard. Mater. 152, 506-515.

Kreysa, G., Wiesner, J. (Eds.), 1995. Bioassays for Soils. DECHEMA (Deutsche Gesellschaft für Chemisches Apparatewesen, Chemiche Technik und Biotechnologie) e.V., Frankfurt am Main.

Křístková, E., Doležalová, I., Lebeda, A., Vinter, V., Novotná, A., 2008. Description of morphological characters of lettuce (Lactuca sativa L.) genetic resources. HortScience 35, 113-129.

Lebeda, A., Ryder, E.J., Grube, R., Doležalová, I., Kř̌istková, E., 2007. Lettuce (Asteraceae; Lactuca spp.). In: Singh, R.J. (Ed.), Genetic Resources, Chromosome Engineering, and Crop Improvement, vol. 3. Vegetable Crops. Tailor and Francis Group, CRC Press, Boca Raton, pp. 377-472.

Lee, W., An, Y., Yoon, H., 2008. Toxicity and bioavailability of copper nanoparticles to the terrestrials plants mung bean (Phaseolus radiatus) and wheat (Triticum awstivum): plant uptake for water insoluble nanoparticles. Environ. Toxicol. Chem. 27, 1915-1921.

Lin, D., Xing, B., 2007. Phytotoxicity of nanoparticles: inhibition of seed germination and root growth. Environ. Pollut. 150, 243-250.

Lin, D., Xing, B., 2008. Root uptake and phytotoxicity of $\mathrm{ZnO}$ nanoparticules. Environ. Sci. Technol. 42, 5580-5585.

Liu, X., Zhang, S., Shan, X., Zhu, Y.G., 2005. Toxicity of arsenate and arsenite on germination, seedling growth and amylolytic activity of wheat. Chemosphere 61, 293-301.

Lock, K., Janssen, C.R., 2001. Ecotoxicity of zinc in spiked artificial soils versus contaminated field soils. Environ. Sci. Technol. 35, 4295-4300.

Lock, K., Janssen, C.R., 2002. The effect of ageing on the toxicity of zinc for the potworm Enchytraeus albidus. Environ. Pollut. 116, 289-292.

Lock, K., Janssen, C.R., 2003a. Influence of aging on $\mathrm{Zn}$ bioavailability in soils. Environ. Pollut. 126, 371-374.

Lock, K., Janssen, C.R., 2003b. Influence of aging on copper bioavailability in soils. Environ. Toxicol. Chem. 22, 1162-1166.

Loureiro, S., Ferreira, A.L.G., Soares, A.M.V.M., Nogueira, A.J.A., 2005. Evaluation of the toxicity of two soils from Jales Mine (Portugal) using aquatic bioassays. Chemosphere 61, 168-177.

Lu, A., Zhang, S., Qin, X., Wu, W., Liu, H., 2009. Aging effect on the mobility and bioavailability of copper in soil. J. Environ. Sci. 21, 173-178.

Ma, X., Geiser-Lee, J., Deng, Y., Kolmakov, A., 2010a. Interactions between engineered nanoparticles (ENPs) and plants: phytotoxicity, uptake and accumulation. Sci. Total Environ. 16, 3053-3061.

Ma, Y., Kuang, L., He, X., Bai, W., Ding, Y., Zhang, Z., Zhao, Y., Chai, Z., 2010b. Effects of rare earth oxide nanoparticles on root elongation of plants. Chemosphere 78 273-279.

Martínez, C.E., Jacobson, A.R., McBride, M.B., 2003. Aging and temperature effects on DOC and elemental release from a metal contaminated soil. Environ. Pollut. 122, 135-143.

Meers, E., Samson, R., Tack, F.M.G., Ruttens, A., Vandegehuchte, M., Vangronsveld, J., Verloo, M.G., 2007. Phytoavailability assessment of heavy metals in soils by single extractions and accumulation by Phaseolus vulgaris. Environ. Exp. Botany 60, 385-396.
Moore, M.N., 2006. Do nanoparticles present ecotoxicologiocal risks for the health of the aquatic environment. Environ. Int. 32, 967-976.

Morones, J.R., Elechiguerra, J.L., Camacho, A., Holt, K., Kouri, J.B., Ramirez, J.T. Yacaman, M.J., 2005. The bactericidal effect of silver nanoparticles. Nanotechnol $16,2346-2353$.

Nair, R., Varghese, S., Nair, B., Maekawa, T., Yoshida, Y., Kumar, D., 2010 Nanoparticulate material delivery to plants. Plant Sci. 179, 154-163.

Nel, A., Xia, T., Mädler, L., Li, N., 2006. Toxic potential of materials at the nanolevel. Science 311, 622-627.

Nowack, B., Bucheli, T.D., 2007. Occurrence, behavior and effects of nanoparticles in the environment. Environ. Pollut. 150, 5-22.

Ohmsen, G.S., 2001. Characterization of fugitive material within a primary lead smelter. J. Air Waste Manage. Assoc. 51, 1443-1451.

Pal, S., Tak, Y.K., Song, J.M., 2007. Does the antibacterial activity of silver nanoparticles depend on the shape of the nanoparticle? A study of the gramnegative bacterium Escherichia coli. Appl. Environ. Microbiol. 73, 1712-1720.

Perrone, M.G., Gualtieri, M., Ferrero, L., Lo Porto, C., Udisti, R., Bolzacchini, E., Camatini, M., 2010. Seasonal variations in chemical composition and in vitro biological effects of fine PM from Milan. Chemosphere 78, 1368-1377.

Polichetti, G., Cocco, S., Spinali, A., Trimarco, V., Nunziata, A., 2009. Effects of particulate matter $\left(\mathrm{PM}_{10}, \mathrm{PM}_{2.5}\right.$ and $\left.\mathrm{PM}_{1}\right)$ on the cardiovascular system. Toxicology 261, 1-8.

Richards, B.K., Steenhuis, T.S., Peverly, J.H., McBride, M.B., 2000. Effect of sludgeprocessing mode, soil texture and soil $\mathrm{pH}$ on metal mobility in undisturbed soil columns under accelerated loading. Environ. Pollut. 109, 327-346.

Rink, K.H., Kordel, W., Hennecke, D., Eisentraeger, A., Heiden, S., 2002. Bioassays for the Ecotoxicological and Genotoxicological Assessment of contaminated soils (Results of a Round Robin Test): Part I. Assessment of a possible groundwate contamination: ecotoxicological and genotoxicological tests with aqueous soil extracts. J. Soil Sediment 2, 43-50.

Robidoux, P.Y., Gonga, P., Sarrazin, M., Bardai, G., Paquet, L., Hawari, J., Dubois, C. Sunahara, G.I., 2004. Toxicity assessment of contaminated soils from an antitank firing range. Ecotoxicol. Environ. Saf. 58, 300-313.

Rubatzky, V.E., Yamaguchi, M., 1997. World Vegetables. Chapman \& Hall, New York

Sammut, M., 2007. Spéciation du Cadmium, du Plomb et du Zinc Dans les Poussières d'émissions Atmosphériques d'origine Sidérurgique. Approche de l'impact Toxicologique des Poussières. CEREGE - UMR 6635 CNRS, Université AM III, $333 \mathrm{p}$.

Shahid, M., Pinelli, E., Pourrut, B., Silvestre, J., Dumat, C., 2011. Lead-induced genotoxicity to Vicia faba $L$. roots in relation with metal cell uptake and initial speciation. Ecotoxicol. Environ. Saf. 74, 78-84.

Sheehan, P., Dewhurst, R.E., James, S., Callaghan, A., Connon, R., Crane, M., 2003. Is there a relationship between soil and groundwater toxicity? Environ. Geochem. Health 25, 9-16.

Singh, A., Agrawal, M., Marshall, F.M., 2010. The role of organic vs. inorganic fertilizers in reducing phytoavailability of heavy metals in a wastewaterirrigated area. Ecol. Eng. 36, 1733-1740.

Stampoulis, D., Sinha, S.K., White, J.C., 2009. Assay-dependent phytotoxicity of nanoparticles to plants. Environ. Sci. Technol. 43, 9473-9479.

Strigul, N., Vaccari, L., Galdun, C., Wazne, M., Liu, X., Christodoulatos, C. Jasinkiewicz, K., 2009. Acute toxicity of boron, titanium dioxide, and aluminum nanoparticles to Daphnia magna and Vibrio fischeri. Desalination 248, 771-782.

Tiquia, M.S., Tam, N.F.Y., Hodgkiss, I.J., 1996. Effects of composting on phytotoxicity of spent pig-manure sawdust litter. Environ. Pollut. 93, 249-256.

Udovic, M., Lestan, D., 2009. Pb, Zn and Cd mobility, availability and fractionation in aged soil remediated by EDTA leaching. Chemosphere 74, 1367-1373.

Uzu, G., Sobanska, S., Aliouane, Y., Pradere, P., Dumat, C., 2009. Study of lead phytoavailability for atmospheric industrial micronic and sub-micronic particles in relation with lead speciation. Environ. Pollut. 157, 1178-1185.

Uzu, G., Sobanska, S., Sarret, G., Munoz, M., Dumat, C., 2010. Foliar lead uptake by lettuce exposed to atmospheric fallouts. Environ. Sci. Technol. 44, 1036-1042.

Uzu, G., Sobanska, S., Sarret, G., Sauvain, J.J., Pradère, P., Dumat, C., in press Characterization of lead-recycling facility emissions at various workplaces: major insights for sanitary risk assessment. J. Hazard. Mater. doi:10.1016/ j.jhazmat.2010.11.086.

Vila, M., Mehier, S., Lorber-Pascal, S., Laurent, F., 2007. Phytotoxicity to and uptake of RDX by rice. Environ. Pollut. 145, 813-817.

Wang, X.D., Sun, C., Gao, S.X., Wang, L.S., Han, S.K., 2001. Validation of germination rate and root elongation as indicator to assess phytotoxicity with Cucumis sativus. Chemosphere 44, 1711-1721.

Warheit, D.B., Hoke, R.A., Finlay, C., Donner, E.M., Reed, K.L., Sayes, C.M., 2007 Development of a base set of tests using ultrafine $\mathrm{TiO}_{2}$ particles as a component of nanoparticles risk management. Toxicol. Lett. 171, 99-110.

Wierzbicka, M., Obidzinska, J., 1998. The effect of lead on seed imbibition and germination in different plant species. Plant Sci. 137, 155-171.

Yang, L., Watts, D.J., 2005. Particle surface characteristics may play an importan role in phytotoxicity of alumina nanoparticles. Toxicol. Lett. 158, 122-132.

Yin, Y., Impellitteri, C.A., You, S.J., Allen, H.E., 2002. The importance of organic matter distribution and exact soil: solution ratio on the desorption of heavy metals from soils. Sci. Total Environ. 287, 107-119.

Zapusek, U., Lestan, D., 2009. Fractionation, mobility and bio-accessibility of $\mathrm{Cu}, \mathrm{Zn}$, $\mathrm{Cd}, \mathrm{Pb}$ and $\mathrm{Ni}$ in aged artificial soil mixtures. Geoderma 154, 164-169.

Zhang, Z., Kleinstreuer, C., Donohue, J., Kim, C., 2005. Comparison of micro- and nano-size particle depositions in a human upper airway model. J. Aerosol Sci. $36,211-233$. 